\title{
Assessment of Social Capital in the Work with Suppliers: A Case of a Tourist Organization
}

\author{
Svetlana Orekhova*, Vera Zarutskaya
}

Ural State University of Economics, Ekaterinburg, Russia

*Corresponding author.Email: bentarask@list.ru

\begin{abstract}
The article is devoted to the development of an original methodology for measuring the social capital of an organization with suppliers. The methodological basis of the study is a combination of the theory of social capital and the network approach. The research methods are structural and economic analysis and survey. The author's methodology for assessing social capital is based on a consistent assessment of its three components: structural, relational and cognitive. The approbation of the proposed methodological tools was carried out in the tourist organization of the Sverdlovsk region. The portfolio of relationships with suppliers was evaluated. The proposed methodology is universal and testifies to the influence of social capital on the efficiency of business.
\end{abstract}

Keywords: Social capital, Networks, Sustainability, Tourism market, Management.

\section{INTRODUCTION}

The extension of the regime of restrictions related to the COVID-19 pandemic is a key factor in the instability of tourist markets at all levels [1]. The preservation of the tourism business requires firms to revise strategies, consolidate various resources, including implicit ones.

One of these resources is social capital, which is understood as an income-generating resource, as well as a network of access to resources for the firm to achieve its goals. [2] The measurement of social capital is a nontrivial scientific task that allows managing relationships with counterparties.

The purpose of this study, therefore, is to develop and further test methodological tools for assessing social capital on the example of a tourist organization. To achieve the goal, it is required: to determine the structure of the elements of social capital; to propose an algorithm for their evaluation; to test the methodology on the example of a specific firm.

\section{METHOD}

Depending on the specifics of the business model [3], it is possible to evaluate the entire portfolio of relationships or its individual parts, the main of which are relationships with suppliers and buyers. The structure of the components of social capital (Fig. 1), consisting of structural, relational and cognitive parts [6-8] and adapted to the tasks of the case study of a particular organization.

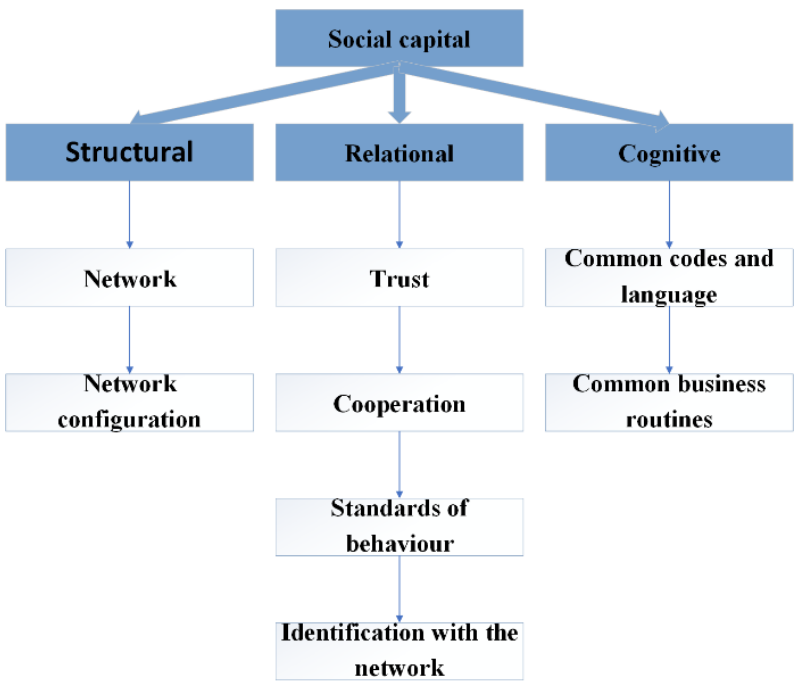

Figure 1. The structure of the elements of the organization's social capital $[4,5]$. 


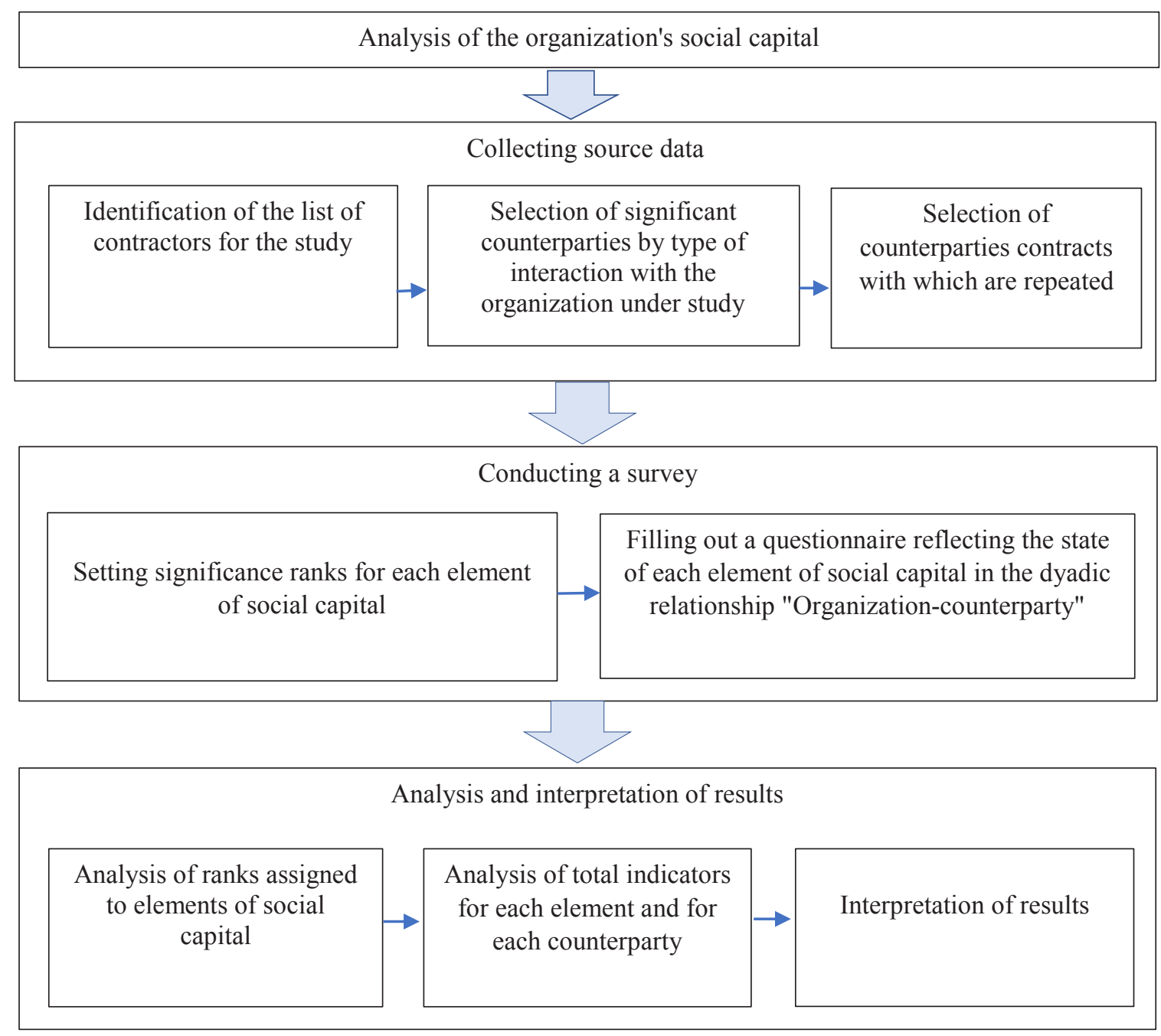

Figure 2. Methodology for social capital of the organization analysis

The algorithm for the study of the social capital of an organization is presented in Fig. 2.

In this study, we will focus on assessing the level of social capital of an organization when working with suppliers.

The first stage is the collection of initial data. The formation of a sample of counterparties is based on the organization's data. Then, several counterparties were excluded, in particular those, transactions with which were not numerous (no more than 1 in the last 3 years) and/or whose activities have been suspended due to their liquidation (that is, the connection is irrelevant and cannot be updated).

The second stage - obtaining data on the significance and degree of application of the components of social capital - is carried out using a questionnaire based on the structure of social capital.

At first, the significance rank of each component [9] of social capital is determined for new contracts with the supplier: 1 - has a decisive influence on further contracts with the supplier; 0.5 - has an impact on repeated contract with this supplier; 0.25 - has a minor impact on contacting this supplier; 0 - does not matter for the work of the organization under study. This scale serves as an indicator of network interactions of the market in which the organization operates [10]. If the rank "1" prevails, then the criteria of social capital are crucial for the selection of the same suppliers in each subsequent transaction. The predominance of a low rank will indicate that social capital itself is not of great importance in the selection of a supplier and the organization's decisive selection criteria in the market are different (for example, prices, uniqueness of the product offer, lack of choice of suppliers in this market, etc.).

Then the representative of the organization gives answers to questions that establish a connection between each element of social capital on a scale from 0 to 3.0 means the absence of the studied component in the, relationship with this supplier, 3 - the maximum 
presence of this component of social capital in the relationship with the supplier.

The calculation of the total indicators is made by multiplying the score by the rank set for each component of social capital.

\section{RESULTS}

Approbation of the proposed methodology was carried out on the example of the travel agency LLC "Travel Company "Velvet Season" (hereinafter referred to as the Organization), registered in Yekaterinburg in 2014. The activity of the travel agency is the promotion and sale of tourist services of varying complexity to consumers. The portfolio of relationships of a travel agency can be represented by relationships with different types of counterparties:

- consumers (mainly individuals);

- $\quad$ suppliers of tourist services for further sale to agency buyers for a commission fee;

- providers of services to ensure the conduct of the organization's activities: rental of premises, settlement and cash services, etc. In this case, the portfolio of relationships with contractors-suppliers for the main type of activity was studied. 23 suppliers were selected that met all the criteria: the supplier exists at the moment, over the past 3 years, 2 or more transactions have been made between the supplier and the Organization. Grouping was also carried out in the case when one supplier has several legal entities to conduct business.

The first part of the survey involves setting the rank of importance of each component of social capital for relations with suppliers in this market. The results are presented in Table 1.

The results obtained allow us to outline the profile of the significance of the components of social capital in this market and for this type of activity. The most significant component of social capital in an Organization's relationship with suppliers is the structural component. In particular, the frequency of relationships and the presence of a common business structure (brand, voluntarily accepted obligations in exchange for promotion, etc.), obliging to maintain ties, will be of maximum importance for making a repeat of the transaction with the supplier. The relational and cognitive components are defined as equally significant by the rank. Among the most important are: trust in the supplier; the presence of privileges, bonuses in working with this supplier; the presence of familiar routines, business procedures, a permanent contact person, ensuring the speed and ease of making new transactions. An integral significance score (4.75 out of 9) means a high importance of social capital when re-contacting the supplier, but it is not decisive. That is, in this market, for travel agents' transactions with travel service providers, there are other important factors leading to transactions, including repeated ones.

Table 1. Significance ranks of capital components

\begin{tabular}{|l|l|}
\hline Component of social capital & $\begin{array}{l}\text { Significance of this } \\
\text { component }\end{array}$ \\
\hline 1. Structural Component & 0,83 out of 1 \\
\hline 1.1 Duration of the relationship & 0,5 \\
\hline 1.2 Frequency of interaction & 1 \\
\hline $\begin{array}{l}\text { 1.3. The presence of a common } \\
\text { business structure }\end{array}$ & 1 \\
\hline 2. Relational component & 0,375 out of 1 \\
\hline $\begin{array}{l}\text { 2.1Trust in this supplier based on the } \\
\text { experience of past transactions }\end{array}$ & 0,5 \\
\hline $\begin{array}{l}\text { 2.2. Cooperation, joint events, } \\
\text { organization of training, targeted } \\
\text { notification }\end{array}$ & 0,25 \\
\hline $\begin{array}{l}\text { 2.3. Norms. If this supplier violates } \\
\text { the generally accepted norms of } \\
\text { business ethics in the network }\end{array}$ & 0,25 \\
\hline $\begin{array}{l}\text { 2.4. Belonging to a closed circle of } \\
\text { participants, which is a source of } \\
\text { privileges }\end{array}$ & 0,5 \\
\hline 3.Cognitive component & 0,375 out of 1 \\
\hline $\begin{array}{l}\text { 3.1. Availability of a clear way of } \\
\text { providing information (for tourism - } \\
\text { booking system / website) }\end{array}$ & 0,25 \\
\hline $\begin{array}{l}\text { 3.2. The presence of familiar business } \\
\text { routines in interaction with the } \\
\text { supplier, a permanent contact person }\end{array}$ & 0,5 \\
\hline $\begin{array}{l}\text { Integral significance of social capital } \\
\text { criteria }\end{array}$ & 4,75 out of 9 \\
\hline
\end{tabular}

It is also advisable to estimate the total and weighted score for each component of social capital in a specific portfolio of suppliers of a particular Organization under study (Table 2).

Based on the indicators of the integral significance of the components of social capital for a specific portfolio of suppliers of LLC "Travel Company "Velvet Season", it can be concluded that social capital is significant for repeated transactions. However, since the total and total weighted scores are $53.8 \%$ and $48.2 \%$ of the maximum values, respectively, we can say that there are other important criteria for making transactions (including repeated ones) with these suppliers. The maximum indicator of significance has a cognitive component of social capital; the minimum indicator of significance has a structural component of social capital. When viewed in the context of sub-components, the duration of the relationship, the presence of familiar business routines and a permanent contact person, trust in the supplier, compliance with business norms and ethics by the supplier are of maximum importance. The presence of a common business structure with suppliers is of minimal importance, since it is not used at all for this Organization, belonging to a closed club of participants, cooperation with a supplier in addition to the main activity. 
Table 2. Weighted score of social components of capital for a portfolio of suppliers of LLC "Travel company" Velvet Season "

\begin{tabular}{|c|c|c|c|c|c|c|}
\hline Component of social capital & $\begin{array}{l}\text { The total } \\
\text { score of this } \\
\text { criterion }\end{array}$ & Maximum & $\begin{array}{l}\% \text { of the } \\
\text { maximum }\end{array}$ & $\begin{array}{l}\text { Weighted } \\
\text { score of this } \\
\text { criterion for }\end{array}$ & $\begin{array}{l}\text { Maximum } \\
\text { possible } \\
\text { weighted } \\
\text { score }\end{array}$ & $\begin{array}{l}\% \text { of the } \\
\text { maximum }\end{array}$ \\
\hline 1. Structural Component & 100 & 207 & 48,3 & 70,5 & 172,5 & 40,9 \\
\hline $\begin{array}{l}\text { 1.1 Duration of the } \\
\text { relationship }\end{array}$ & 59 & 69 & 85,5 & 29,5 & 34,5 & 85,5 \\
\hline 1.2 Frequency of interaction & 41 & 69 & 59,4 & 41 & 69 & 59,4 \\
\hline $\begin{array}{l}\text { 1.3. The presence of a } \\
\text { common business structure }\end{array}$ & 0 & 69 & 0 & 0 & 69 & 0 \\
\hline 2. Relational component & 139 & 276 & 50,4 & 51 & 103,5 & 49,3 \\
\hline $\begin{array}{l}2.1 \text { Trust in this supplier based } \\
\text { on the experience of past } \\
\text { transactions }\end{array}$ & 51 & 69 & 73,9 & 24,5 & 34,5 & 73,9 \\
\hline $\begin{array}{l}\text { 2.2. Cooperation, joint events, } \\
\text { organization of training, } \\
\text { targeted notification }\end{array}$ & 24 & 69 & 34,8 & 6 & 17,25 & 34,8 \\
\hline $\begin{array}{l}\text { 2.3. Norms. If this supplier } \\
\text { violates the generally } \\
\text { accepted norms of business } \\
\text { ethics in the network }\end{array}$ & 50 & 69 & 72,5 & 12,2 & 17,25 & 72,5 \\
\hline $\begin{array}{l}\text { 2.4. Belonging to a closed } \\
\text { circle of participants, which is } \\
\text { a source of privileges }\end{array}$ & 14 & 69 & 20,3 & 7 & 34,5 & 20,3 \\
\hline 3.Cognitive component & 95 & 138 & 68,8 & 36,5 & 51,75 & 70,5 \\
\hline $\begin{array}{l}\text { 3.1. Availability of a clear } \\
\text { way of providing information } \\
\text { (for tourism - booking system } \\
\text { / website) }\end{array}$ & 44 & 69 & 63,8 & 11 & 17,25 & 63,8 \\
\hline $\begin{array}{l}\text { 3.2. The presence of familiar } \\
\text { business routines in } \\
\text { interaction with the supplier, } \\
\text { a permanent contact person }\end{array}$ & 51 & 69 & 73,9 & 25,5 & 34,5 & 73,9 \\
\hline $\begin{array}{l}\text { Integral significance of social } \\
\text { capital criteria }\end{array}$ & 334 & 621 & 53,8 & 158 & 327,75 & 48,2 \\
\hline
\end{tabular}

\section{CONCLUSION}

The revision of social capital in the resource portfolio of firms is a relatively new practice. Despite the fact that long-term relationships with counterparties are common in business, their analysis from the standpoint of scientific management theories is not practiced.

Social capital can be assessed by a firm as a set of structural, relational and cognitive practices of doing business with permanent counterparties. The selfdiagnosis procedure includes setting the ranks of importance by an element of social capital and scoring their use in dyadic relations with each counterparty.

The methodology has been tested on the portfolio of relations between a travel company and suppliers. But it can be applied to organizations of different profiles and to analyze relationships with different types of counterparties.

\section{REFERENCES}

[1] UNWTO World Tourism Barometer and Statistical Annex, May 2021 UNWTO World Tourism Barometer (English version), 19(3). DOI: https://www.e-

unwto.org/doi/epdf/10.18111/wtobarometereng.202 1.19.1.3.

[2] S. Orekhova, V. Zarutskaya, Yu. Bausova, Social capital in the system of corporate sustainability in: E3S Web of Conferences, 208 (2020) 07004. DOI: https://doi.org/10.1051/e3sconf/202020807004.

[3] A. Osterwalder,Y. Pigneur, C. Tucci, Clarifying business models: Origins, present, and future of the concept in: Communications of the Association for In-formation Systems, 16 (2005) pp. 1-25. DOI: http://citeseerx.ist.psu.edu/viewdoc/download?doi= 10.1.1.83.7452\&rep=rep1\&type=pdf.

[4] W. Zhao, J.R.B. Ritchie, C.M. Echtner, Social capital and tourism entrepreneurship in: Annals of 
Tourism Research, 38(4) (2011) pp. 1570-1593. DOI: https://doi.org/10.1016/j.annals.2011.02.006.

[5] C. H. S. Liu, Examining Social Capital, Organizational Learning and Knowledge Transfer in Cultural and Creative Industries of Practice in: Tourism Management, 64 (2018) pp. 258-270. DOI:

https://doi.org/10.1016/j.tourman.2017.09.001.

[6] J. Kemper, O. Schilke, M. Brettel, Social capital as a micro-level origin of organizational capabilities in: Journal of Product Innovation Management, 30(3) (2013) pp. 589-603. DOI: http://dx.doi.org/10.2139/ssrn.2045744.

[7] J. Nahapiet, S. Ghoshal S., Social capital, intellectual capital and the organizational advantage in: Academy of management review, 23(2) (1998) pp. 242-266. DOI: https://doi.org/10.2307/259373.

[8] M. Paldam, Social Capital: One or Many? Definition and Measurement in: Journal of Economic Surveys, 14(5) (2000) pp. 629-653. DOI: https://doi.org/10.1111/1467-6419.00127.

[9] V.V. Podinovskiy, Ideas and methods of the theory of the importance of criteria in multicriteria decision-making problems in: Science, Moscow, (2019).

[10] S.V. Orekhova, V. S. Zarutskaya, E.V. Kislitsyn, An empirical investigation of network relationships in the market in: Upravlenets - The Manager, 12(1) (2021) pp. 32-46. DOI: 10.29141/2218-5003-202112-1-3. 